\title{
Phytochemical Analysis and Anti-diabetic Activity of Leaf extract of Psydrax horizontalis Schum. \& Thonn (Rubiaceae)
}

\author{
Onyekere Peculiar Feenna ${ }^{1,2 *}$, Odoh Uchenna Estella', Ezugwu Christopher Obodike ${ }^{1}$
}

\section{Onyekere Peculiar Feenna ${ }^{1,2 *}$, Odoh Uchenna Estella ${ }^{1}$, Ezugwu Christopher Obodike}

'Department of Pharmacognosy and Faculty of Pharmaceutical Sciences, University of Nigeria, Nsukka. 410001. Enugu State, Nigeria.

${ }^{2}$ Department of Health Sciences, Hamburg University of Apllied Sciences, HAW-

Hamburg, Germany.

\section{Correspondence}

\section{Onyekere Peculiar Feenna}

Department of Pharmacognosy \& Environmental Medicine, Faculty of Pharmaceutical Sciences, University of Nigeria, Nsukka. 410001. Enugu State, NIGERIA.

Phone no: +2348068068346

E-mail: peculiar.onyekere@unn.edu.ng

History

- Submission Date: 07-06-2019;

- Review completed: 28-06-2019;

- Accepted Date: 11-07-2019.

DOI : 10.5530/pj.2020.12.15

Article Available online http://www.phcogj.com/v12/i1

\section{Copyright}

(C) 2020 Phcogj.Com. This is an openaccess article distributed under the terms of the Creative Commons Attribution 4.0 International license.

\begin{abstract}
Introduction: Rubiacaeae is a large family of flowering plants of 630 genera with over 13000 species widely distributed in the tropical and warm regions of the world. The Psydrax genus has been reported to have various pharmacological activities. Based on ethno-pharmacological information, Psydrax horizontalis Schum. \& Thonn. (Bridson) locally known as "Akata-ike" in Nsukka is used in the management of diabetes in South-eastern Nigeria. However as at the time of this research, no previous work has been done to investigate its phytochemical constituents and anti-diabetic activity. Methods: The methanol extract (ME) obtained by maceration was analysed for phytochemicals present using standard procedures. Alloxan monohydrate at 150 $\mathrm{mg} / \mathrm{Kg}$ was used to induce diabetes. Acute toxicity test was done using the Lorke's method. The normoglycemic and alloxan-induced groups of twenty animals each were treated orally with 100,200 and $400 \mathrm{mg} / \mathrm{Kg}$ of ME; $5 \mathrm{mg} / \mathrm{Kg}$ of glibenclamide and $2 \mathrm{~mL} / \mathrm{kg}$ of $3 \%$ Tween 80 as the controls. The fasting blood glucose concentrations were monitored at $0,1,3$ and $6 \mathrm{~h}$, as well as $1^{\text {st }}, 3^{\text {rd }}$ and $5^{\text {th }}$ day. Results: Phytochemical screening revealed the presence of glycosides, alkaloids, tannins, flavonoids, steroids, saponins and terpenoids. Median lethal dose was greater than $5000 \mathrm{mg} / \mathrm{kg}$. In the alloxan-induced diabetic rats, significant activity at $p<0.01$ on the $6^{\text {th }}$ hour was recorded at doses 100, 200 and $400 \mathrm{mg} / \mathrm{Kg} \mathrm{ME}$ on day 3 . Conclusion: The ME of Psydrax horizontalis possesses significant anti-diabetic activity in the alloxan-induced diabetic rats. The results obtained validate its traditional use in management of diabetes.
\end{abstract}

Key words: Diabetes, Alloxan monohydrate, Extraction, Flavonoids.

\section{INTRODUCTION}

Diabetes is one of the world's most chronic diseases characterized by persistent hyperglycemia with associated metabolic disorder. ${ }^{1}$ Diabetes mellitus is the 8th major leading cause of death worldwide affecting $4 \%$ of the global population. Its damage to many of the body's systems particularly the nerves and the blood vessels makes it a significant health concern to the developing and developed countries. $^{2}$

Diabetes mellitus has no curative therapy irrespective of the various claims by trado-medical practitioners of having the cure. It belongs to the groups of ailments such as AIDS, cancer and hypertension that can presently only be managed. ${ }^{3}$ It is majorly classified as Type 1 and Type 2 . Type 1 occurs due to cellular mediated autoimmune destruction of $\beta$-cells of the pancreas which invariably leads to absolute insulin deficiency.

In the type 2 , the beta-cells of the pancreas are capable of producing insulin but become so resistant that the insulin produced is ineffective. ${ }^{4}$ Type 2 diabetes may range from predominantly insulin resistance with relative insulin deficiency to a predominantly secretary defect with or without insulin resistance.

Conventionally, Type I diabetes is treated with exogenous insulin and Type 2 with oral hypoglycemic agents such as sulfonylureas, biguanides, thaizolinedindiones, etc,.${ }^{5}$ However the adverse reactions and side effects associated with them have posed limitations to their therapeutic use. This has invariably given rise to search for potent medicinal plants with anti-diabetic activity of natural origin.

Medicinal plants from antiquity have served as sources of herbal medicines for the treatment of various ailments. According to the World Health Organization, there are over 1200 plant species worldwide with potential anti-diabetic activity and a significant number of them have proven effective after various laboratory tests. ${ }^{6}$ Some plants in Nigeria have been studied for their hypoglycemic and antidiabetic activity- Acanthus montanus ${ }^{3}$ Anthocleista vogelii. ${ }^{7,8}$

Psydrax is a Greek word meaning a blister or bump. It is a genus of flowering plants in the Rubiaceae family, made up of trees, shrubs and some lianas in the paleotropics. It was named by a German botanist, Joseph Gaertner in 1788 in his book called "De fructibus et seminibus plantarum". ${ }^{9}$ However the name was not used because most authors placed the species in Canthium. ${ }^{10}$ Psydrax was reinstated in 1985 and 37 African species transferred to it from the Canthium genera. ${ }^{11}$

Psydraxparviflorum, a closely related specie of Psydrax horizontalis is used as laxative and also to cure gout in Ayurvedic system of medicine. Pharmacological 
activities such as anthelmintic, anti-dysenteric, antispasmodic and as a diuretic have been reported. ${ }^{12}$ Traditionally the roots and leaves are used to cure vitiated conditions of kapha in constipation and fever. The leaf is used as an astringent and has wound healing property..$^{13}$ Psydrax parviflorum as an herbal medicine is used for the treatment of diabetes among major tribal groups in South Tramilnadu. ${ }^{14}$

Psydrax horizontalis Schum. \& Thonn. (Bridson) commonly known as "Akata-ike" in Southeastern Nigeria (Figure 1) is a member of the Rubiaceae family. It is a petiolate, stipulate and compound bipinnate leaf with reticulate venation, entire margin, chordate base, and pubescent leaf surface. The organoleptic characters of the fresh and powdered leaves indicate that it has a smooth adaxial surface, slightly rough abaxial surface, sharp bitter taste, and a lemon green colour.

Psydrax horizontalis leaves are used in the management of diabetes based on ethno-pharmacological information. However as at the time of this research, no previous work has been done to investigate its anti-diabetic activity. The objective of this research is to investigate the phytochemical constituents and scientifically validate the anti-diabetic activity of leaf extract of Psydrax horizontalis.

\section{MATERIALS AND METHODS}

\section{General chemicals/solvents/drugs}

The chemicals, solvents and reagents used were of analytical gradeAlloxan monohydrate (Qualikems, India), glibenclamide (Hovid, USA), methanol (Sigma, USA), tween 80 (Nigeria) and normal saline (Nigeria).

\section{Reagents}

Reagents used for the phytochemical analyses include the following; Mayer's reagent, Wagner's reagent, Dragendorff's reagent, Picric acid, Distilled water, Molisch's reagent, Lead sub-acetate, Concentrated Sulphuric acid, Dilute hydrochrolic acid, Sodium hydroxide Ammonium hydroxide, Glacial acetic acid, Chloral hydrate, Glycerin, Fehlings solution I\& II, Olive oil, 10\% Ferric chloride, Ethylacatate, Chloroform, Sodium hypchlorite, Iodine.

\section{Equipment}

Acuu Chek glucometer (Roche, UK), thermostatic waterbath (B.Bran, England), thermoscientic furnance (USA), rotary evaporator (Stuart, UK), electronic scale (G\&G, USA).

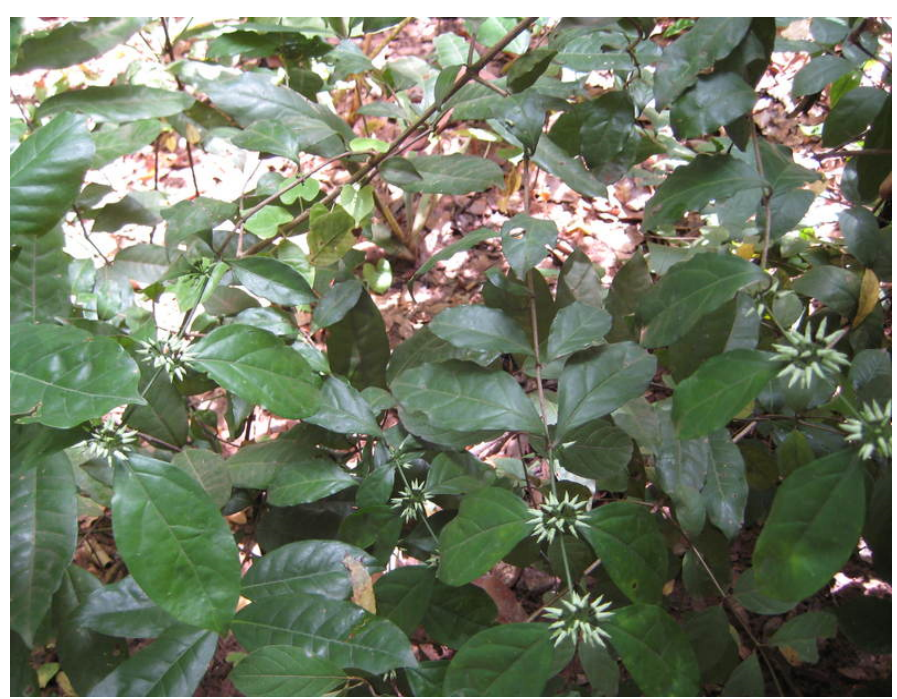

Figure 1: Photograph showing the whole plant and leaves of Psydrax horizontalis growing in Nsukka Habitat.
Collection, identification and preparation of plant materials

The samples of Psydrax horizontalis leaves were collected in Nsukka Local Government in Enugu State, Nigeria in May, 2017. The plant was identified and authenticated by Mr. Felix Nwafor, curator and taxanomist of Department of Pharmacognosy and Environmental Medicines, University of Nigeria, Nsukka. A sample of the plant material was deposited in our hebarium under voucher specimen number PCG/ $\mathrm{UNN} / 0218$ for future reference. After authentication, the fresh leaves were air-dried (under shade) for one week and was pulverized in a grinder to obtain coarse powder. The plant powder was weighed and used for extraction and anti-diabetic studies.

The powdered leaves $(2 \mathrm{~kg})$ were extracted exhaustively by cold maceration at room temperature using absolute methanol in a stoppered container. The mixture was left for 72 hours with occasional shaking. It was then filtered using a Whattman No. 1 filter paper on a funnel. The filtrate was then concentrated at a controlled temperature of $40^{\circ} \mathrm{C}$ under reduced pressure using a STUART rotary vacuum evaporator to obtain the crude methanol extract (ME). The percentage yield of the extract was determined. The extract was transferred into sterile sample containers and preserved at $4^{\circ} \mathrm{C}$ in a refrigerator until required for the proposed experiment.

\section{Phytochemical analysis}

Qualitative phytochemical tests to detect the presence of various secondary metabolites in the crude extract was carried out using standard procedures. ${ }^{15-17}$

\section{Test for tannins}

$1 \mathrm{~g}$ of the powdered material was boiled with $20 \mathrm{ml}$ of water, filtered and used for the following tests.

Ferric chloride test: $3 \mathrm{ml}$ of the filtrate were added few drops of ferric chloride. A greenish black precipitate indicates the presence of tannins.

Lead acetate test: To a little of the filtrate was added lead acetate solution. A reddish colour indicates the presence of tannins.

\section{Test for saponin}

$20 \mathrm{ml}$ of distilled water was added to $2 \mathrm{~g}$ of the extract and boiled on a hot water bath for 2 minutes. The mixture was filtered while hot and allowed to cool and filtrate was used for the following tests:

Frothing test: $5 \mathrm{ml}$ of the filtrate was diluted with $15 \mathrm{ml}$ of distilled water and shaken vigorously. A stable froth (foam) upon standing indicates the presence of saponins.

Emulsion test: To the frothing solution was added 2 drops of olive oil and the contents shaken vigorously. The formation of emulsion indicates the presence of saponins.

Fehling's test: To $5 \mathrm{ml}$ of the filtrate was added $5 \mathrm{ml}$ of Fehling's solution (equal parts of I and II) and the contents were heated on a water bath. A reddish precipitate which turn brick red on further heating with sulphuric acid indicate the presence of saponins.

Haemolysis test: Two testubes containing $5 \mathrm{ml}$ of a $10 \%$ dilution of blood in normal saline were added $5 \mathrm{ml}$ of normal saline and $5 \mathrm{ml}$ of the extract respectively into which $0.045 \mathrm{~g}$ of sodium chloride has been previously dissolved to render it isotonic with blood. The two testubes were gently shaken and allowed to stand for 5 minutes. The formation of clear red liquid in the second test tube indicate occurrence of haemolysis by the saponin in the extract. 


\section{Test for flavonoids}

A $10 \mathrm{ml}$ of ethyl acetate was added to $0.2 \mathrm{~g}$ of the powder and heated on a water bath for 3 minutes. The mixture was cooled, filtered and the filtrate was used for the following tests.

Ammonium hydroxide test: $4 \mathrm{ml}$ of filtrate was shaken with $1 \mathrm{ml}$ of dilute ammonia solution. The layers were allowed to separate. A yellow colour in the ammoniacal layer indicates the presence of flavonoids.

$1 \%$ Aluminum chloride solution test: Another $4 \mathrm{ml}$ portion of the filtrate was shaken with $1 \mathrm{ml}$ of $1 \%$ aluminum chloride solution. The layers were allowed to separate. A yellow colour in the aluminum chloride layer indicates the presence of flavonoids.

\section{Test for carhohydrates (Molisch's test)}

A $0.1 \mathrm{~g}$ of the powder was boiled with $2 \mathrm{~mL}$ of distilled water and filtered. To the filtrate were added few drops of $\alpha$-naphthol solution in ethanol (Molisch's reagent). Concentrated sulphuric acid was then gently poured down the side of the test tube to form a lower layer. A purple interfacial ring was observed indicating the presence of carbohydrates

\section{Test for glycosides (Combined reducing sugars)}

A $5 \mathrm{~mL}$ of dilute sulphuric acid was added to $0.1 \mathrm{~g}$ of the powder in a test tube, boiled for 15 minutes on a water bath, then cooled and neutralized with $20 \%$ potassium hydroxide solution. $10 \mathrm{~mL}$ of a mixture of equal parts of Fehling solution I and II was added and boiled for 5 minutes. A more dense brick red precipitate indicated the presence of glycosides.

\section{Test for steriods}

A $5 \mathrm{~mL}$ of acetic anhydride was added to $0.5 \mathrm{~g}$ of the powdered sample with $2 \mathrm{~mL} \mathrm{H}_{2} \mathrm{SO}_{4}$. The colour changed from violet to blue indicating the presence of steroids.

Test for Terpenoids (Salkowski test): Five $\mathrm{mL}$ of the extract was mixed in $2 \mathrm{~mL}$ of chloroform

and concentrated $\mathrm{H} 2 \mathrm{~S} 04(3 \mathrm{~mL})$ was carefully added to form a layer. A reddish brown colouration of the inter face was formed to show positive results for the presence of terpenoids.

\section{Test for alkaloids}

A $0.5 \mathrm{~g}$ of the powdered extracts was stirred in $5 \mathrm{~mL}$ of $1 \%$ HClaq on a steam bath for 5 minutes. The mixture was then filtered using Whatman's no1 filter paper. To the filtrate, 2-4drops of Dragendoff's reagent was added to $1 \mathrm{~mL}$ of the filtrate. An orange-red colour was observed indicating the presence of alkaloids.

\section{Test for reducing sugars (Free)}

A $5 \mathrm{~mL}$ of a mixture of equal parts of Fehling's solution I and II were added to $5 \mathrm{~mL}$ of aqueous extract and then heated on a water bath for 5 minutes. A brick red precipitate showed the presence of reducing sugar.

\section{Test for steroids and terpenoids}

A $9 \mathrm{ml}$ of ethanol was added to $1 \mathrm{~g}$ of the powder and refluxed for a few minutes and filtered. The filtrate was concentrated to $2.5 \mathrm{ml}$ on a boiling water bath. $5 \mathrm{ml}$ of hot distilled water was added to the concentrated solution, the mixture was allowed to stand for I hour and the waxy matter was filtered off. The filtrate was extracted with $2.5 \mathrm{ml}$ of chloroform using separating funnel. To $0.5 \mathrm{ml}$ of the chloroform extract in a test tube was carefully added $1 \mathrm{ml}$ of concentrated sulphuric acid to form a lower layer. A reddish brown interface shows the presence of steroids. Another $0.5 \mathrm{ml}$ of the chloroform extract was evaporated to dryness on a water bath and heated with $3 \mathrm{ml}$ of concentrated sulphuric acid for 10 minutes on a water bath. A grey colour indicates the presence of terpenoids.

\section{Experimental animals}

Adult Swiss albino mice (18-25g) of both sex and adult Wistar albino rats $(120-180 \mathrm{~g})$ of either sex were used for the experiments. They were purchased from the Zoological Garden of the Department of Zoology and Environmental Biology, University of Nigeria, Nsukka and acclimatized for seven days before use. They were kept in standard polypropylene cages at room te mperature and at $60-65 \%$ relative humidity during the experimental work. They were fed with normal laboratory diet (Top feeds Nig. Ltd) and allowed to drink water ad libitum. Approval for the use of animal subjects was secured from the Animal Research Ethics Committee, University of Nigeria, Nsukka. The care and handling of animals were in line with the internationally accepted principles for laboratory animal use and care as found in the European Community guidelines. ${ }^{18}$

\section{Acute toxicity and lethality test}

The acute-toxicity and lethality $\left(\mathrm{LD}_{50}\right)$ of the crude methanol extract was determined via the oral route using the method described by Lorke. ${ }^{19}$

\section{Phase One: Determination of the toxic range}

The mice were divided into 3 groups of 3 animals each and treated orally with the crude methanol extract of Psydrax horizontalis leaves at doses of 10, 100 and $1000 \mathrm{mgkg}^{-1}$ body weight. They were observed for 24 hours for signs of toxicity.

\section{Phase two: Determination of lethality}

The doses used in this phase were determined by the number of deaths per dose recorded in phase one. Since no death occurred in all the doses of phase one, three different doses- 1600, 2900 and $5000 \mathrm{mgkg}^{-1}$ were administered orally to other groups of animals at one dose per animal. The treated animals were observed for number of deaths for 24 hours. The $\mathrm{LD}_{50}$ of this test was determined by calculating the geometric mean of the least and most toxic doses

\section{Anti-diabetic studies}

\section{Determination of hypoglycemic activity on normoglycemic rats}

Twenty (20) normoglycemic rats were randomly grouped into five $(n=4)$ and labeled accordingly. They were fasted overnight for 12 hours and then their Fasting Blood Glucose levels were checked with Accuchek $^{\oplus}$ active glucometer. Various treatments were administered orally according to the body weight based on the following experimental design:

$$
\begin{aligned}
& \text { Group } 1 \ldots \ldots \ldots 100 \mathrm{mg} / \mathrm{Kg} \text { of ME } \\
& \text { Group } 2 \ldots \ldots \ldots 200 \mathrm{mg} / \mathrm{Kg} \text { of ME } \\
& \text { Group } 3 \ldots \ldots \ldots . \ldots 00 \mathrm{mg} / \mathrm{Kg} \text { of ME } \\
& \text { Group } 4 \ldots \ldots \ldots . \ldots \mathrm{mg} / \mathrm{Kg} \text { Glibenclamide } \\
& \text { Group } 5 \ldots \ldots \ldots 2 \mathrm{~mL} / \mathrm{Kg} \text { Tween }
\end{aligned}
$$

The Fasting blood glucose concentrations were then monitored at 0,1 , 3 and $6 \mathrm{~h}$, days 1,3 and 5 using the glucometer by withdrawing blood samples from the tail vein of the rats.

\section{Anti-diabetic study of the crude extract on Alloxan-induced diabetic Rats}

The acclimatized rats were kept fasting for $12 \mathrm{~h}$ with water ad libitum and injected intraperitoneally with alloxan monohydrate in distilled water at a dose of $150 \mathrm{mg} / \mathrm{kg}$. After $1 \mathrm{~h}$, the animals were provided with standard laboratory diet ad libitum. The blood glucose level was checked with a blood glucometer before and $48 \mathrm{~h}$ after alloxan administration 
by withdrawing blood from the tip of the tail of each rat under mild anesthesia. Animals were considered diabetic when the blood glucose level was raised beyond $150 \mathrm{mg} / \mathrm{ml}$. The animals were segregated into 5 groups (Groups 1 to 5 ) of four animals in each according to the following experimental protocols.

Group 1 .........100 mg/kg of ME

Group 2 ........ $200 \mathrm{mg} / \mathrm{kg}$ of ME

Group 3........ 400mg/kg of ME

Group 4 ........ $5 \mathrm{mg} / \mathrm{kg}$ Glibenclamide

Group 5 ........ 2 ml/kg 30 \% Tween

The blood glucose concentrations were then monitored at $0,1,3$ and 6 $\mathrm{h}$, days 1,3 and 5 using the glucometer by withdrawing blood samples from the tail vein of the rats.

Table 1: Results of qualitative phytochemical analysis.

\begin{tabular}{cccc}
\hline $\mathrm{S} / \mathrm{N}$ & $\begin{array}{c}\text { Phytochemical } \\
\text { Constituents }\end{array}$ & Test/Reagents & Inference \\
\hline 1. & Carbohydrates & Molisch's test & +++ \\
2. & Reducing sugars & Fehling s reagent & ++ \\
3. & Alkaloids & Dragendorff & +++ \\
4. & Glycosides & dil. $\mathrm{H}_{2} \mathrm{SO}_{4}+$ Fehling Solution I \& II & ++ \\
5. & Saponins & Frothing test & ++ \\
6. & Tannins & Emulsion test & ++ \\
7. & Flavonoids & Ferric chloride & +++ \\
8. & Steroids & Ethanol + Chloroform + conc. $\mathrm{H}_{2} \mathrm{SO}_{4}$ & ++ \\
9. & Terpenoids & Ethanol + Chloroform + conc. $\mathrm{H}_{2} \mathrm{SO}_{4}$ & +++ \\
\hline
\end{tabular}

KEY: $(-)=$ Absent; $(+)=$ Present in trace amounts; $(++)=$ Moderately present; $(+++)=$ Abundantly present.

Table 2: Acute toxicity studies.

\begin{tabular}{lcc}
\hline & Dose $(\mathrm{Mg} / \mathrm{Kg})$ & Mortality \\
\hline Phase One & 10 & \\
& 100 & $0 / 3$ \\
& 1000 & $0 / 3$ \\
Phase Two & & $0 / 3$ \\
& 1600 & \\
& 2900 & $0 / 1$ \\
& 5000 & $0 / 1$ \\
\end{tabular}

\section{Statistical analysis}

The data obtained were analyzed using a statistical software (SPSS version 21) and results expressed as mean \pm SEM. The means were subjected to one way analysis of variance (ANOVA) for determining the significant difference and the significance between the various groups and the control was analyzed further by post hoc. Dunnet's test (2-sided). A p-value $<0.05$ was considered to be significant.

\section{RESULTS}

\section{Extraction yield}

After extraction by maceration, the yield of ME was $310.23 \mathrm{~g}$ resulting in $15.51 \%$ yield.

\section{Phytochemical analysis}

The qualitative phytochemical analysis of the extract showed the presence of various phytochemicals as shown in Table 1.

\section{Toxicological studies}

The results of the acute toxicity study of crude methanol extract of Psydrax horizontalis is shown in Table 2.

\section{Hypoglycemic studies in normoglycemic rats}

The result of the effect of methanol extract (ME) of Psydrax horizontalis in the normoglycemic rats after acute and sub-acute administration is depicted in Table 3.

\section{Anti-diabetic effect in alloxan induced diabetic rats}

The result of the effect of methanol extract (ME) of Psydrax horizontalis in the alloxan induced diabetic rats showed a dose-dependent reduction in blood glucose concentration after acute and sub-acute administration as depicted in Table 4 .

\section{DISCUSSION}

This present study agrees with the already reported secondary metabolites present in the ethanol extract of Psydrax parviflorum, a closely related specie of Psydrax horizontalis by. ${ }^{12}$ In another study, ${ }^{20}$ reported that the aqueous and methanol extracts of Psydrax parviflorum leaves revealed the presence of tannins, alkaloids, flavonoids, saponins, steroids, anthraquinones and reducing sugars.

From the results it can be inferred that Psydrax horizontalis has high level of flavonoids, tannins, terpenoids and phenolic compounds. Flavonoids are polyphenolic compounds with many biochemical properties but the

Table 3: Effect of crude methanol extract of leaves of Psydrax horizontalis in normoglycemic rats.

\begin{tabular}{|c|c|c|c|c|c|c|c|c|}
\hline \multirow{2}{*}{$\begin{array}{l}\text { 으 } \\
\text { ํํ }\end{array}$} & \multirow{2}{*}{ 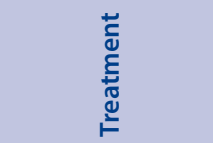 } & \multicolumn{7}{|c|}{ Fasting blood glucose (FBG) concentration (mg / dl) } \\
\hline & & $\mathrm{Oh}$ & $1 \mathrm{~h}$ & $3 \mathrm{~h}$ & $6 \mathrm{~h}$ & Day 1 & Day 3 & Day 5 \\
\hline 1 & $100 \mathrm{mg} / \mathrm{kg}$ of $\mathrm{ME}$ & $118.25 \pm 1.84$ & $\begin{array}{c}111.50 \pm 2.72 \\
(5.71 \%)\end{array}$ & $\begin{array}{c}103.50 \pm 2.72 \\
(12.47 \%)\end{array}$ & $\begin{array}{c}96.00 \pm 4.54 \\
(18.82 \%)\end{array}$ & $\begin{array}{c}86.00 \pm 5.95 \\
(27.27 \%)\end{array}$ & $\begin{array}{c}78.75 \pm 7.88 \\
(33.40 \%)\end{array}$ & $\begin{array}{c}70.25 \pm 6.14 \\
(40.59 \%)\end{array}$ \\
\hline 2 & $200 \mathrm{mg} / \mathrm{kg}$ of $\mathrm{ME}$ & $114.25 \pm 1.93$ & $\begin{array}{c}110.75 \pm 0.75 \\
(3.06 \%)\end{array}$ & $\begin{array}{c}100.25 \pm 3.75 \\
(12.25 \%)\end{array}$ & $\begin{array}{c}89.50 \pm 1.84 \\
(21.66 \%)\end{array}$ & $\begin{array}{c}82.25 \pm 2.68 \\
(28.01 \%)\end{array}$ & $\begin{array}{c}77.00 \pm 3.41 \\
(32.60 \%)\end{array}$ & $\begin{array}{c}65.75 \pm 0.85 \\
(42.45 \%)\end{array}$ \\
\hline 3 & $400 \mathrm{mg} / \mathrm{kg}$ of $\mathrm{ME}$ & $120.00 \pm 1.58$ & $\begin{array}{c}111.25 \pm 2.98 \\
(7.29 \%)\end{array}$ & $\begin{array}{c}96.75 \pm 5.10 \\
(19.38 \%)\end{array}$ & $\begin{array}{c}85.50 \pm 6.29 \\
(28.75 \%)\end{array}$ & $\begin{array}{c}72.75 \pm 4.53^{* *} \\
\quad(39.38 \%)\end{array}$ & $\begin{array}{c}68.00 \pm 2.58 \\
(43.33 \%)\end{array}$ & $\begin{array}{c}58.50 \pm 0.86^{* *} \\
(51.25 \%)\end{array}$ \\
\hline 4 & $\begin{array}{c}5 \mathrm{mg} / \mathrm{kg} \text { of } \\
\text { Glibenclamide }\end{array}$ & $115.50 \pm 2.46$ & $\begin{array}{c}112.50 \pm 1.89 \\
(2.60 \%)\end{array}$ & $\begin{array}{c}107.25 \pm 1.97 \\
(7.14 \%)\end{array}$ & $\begin{array}{c}97.25 \pm 4.38 \\
(15.80 \%)\end{array}$ & $\begin{array}{c}87.50 \pm 4.21 \\
(24.24 \%)\end{array}$ & $\begin{array}{c}78.75 \pm 5.02 \\
(31.82 \%)\end{array}$ & $\begin{array}{c}68.00 \pm 4.96 \\
(41.13 \%)\end{array}$ \\
\hline 5 & 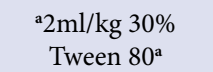 & $119.25 \pm 3.49$ & $\begin{array}{c}117.50 \pm 3.94 \\
\quad(1.47 \%)\end{array}$ & $\begin{array}{c}97.00 \pm 4.65 \\
(1.27 \%)\end{array}$ & $\begin{array}{c}89.00 \pm 6.09 \\
(1.69 \%)\end{array}$ & $\begin{array}{c}85.75 \pm 3.70 \\
(1.97 \%)\end{array}$ & $\begin{array}{c}75.75 \pm 2.32 \\
(2.89 \%)\end{array}$ & $\begin{array}{c}68.50 \pm 1.19 \\
(3.41 \%)\end{array}$ \\
\hline
\end{tabular}

${ }^{a}$ Control group; Results are expressed as mean $\pm \operatorname{SEM}(n=4) ;{ }^{*} p<0.05{ }^{* *} p<0.01$ as compared with control group at the same time; one-way, ANOVA followed by Dunnet's $t$-test); figures in parenthesis denote mean percentage reduction of blood glucose from $0 \mathrm{~h}$. 
Table 4: Effect of crude methanol extract of leaves of Psydrax horizontalis in alloxan induced diabetic rats.

\begin{tabular}{|c|c|c|c|c|c|c|c|c|}
\hline \multirow{2}{*}{$\begin{array}{l}\stackrel{0}{7} \\
\frac{0}{v}\end{array}$} & \multirow{2}{*}{ 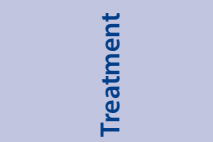 } & \multicolumn{7}{|c|}{ Fasting blood glucose (FBG) concentration (mg/dl) } \\
\hline & & $\mathrm{Oh}$ & $1 \mathrm{~h}$ & $3 \mathrm{~h}$ & $6 \mathrm{~h}$ & Day 1 & Day 3 & Day 5 \\
\hline 1 & $100 \mathrm{mg} / \mathrm{kg}$ of $\mathrm{ME}$ & $324.00 \pm 58.82$ & $\begin{array}{c}226.00 \pm 23.00 \\
(30.25 \%)\end{array}$ & $\begin{array}{c}141.00 \pm 22.68 \\
(56.48 \%) 8^{* *}\end{array}$ & $\begin{array}{c}101.50 \pm 10.14 \\
(68.67 \%)^{* *}\end{array}$ & $\begin{array}{l}94.00 \pm 7.39 \\
(70.99 \%)^{* *}\end{array}$ & $\begin{array}{c}76.00 \pm 4.94 \\
(76.54 \%)^{* *}\end{array}$ & $\begin{array}{c}75.00 \pm 7.82 \\
(76.85 \%)\end{array}$ \\
\hline 2 & $200 \mathrm{mg} / \mathrm{kg}$ of $\mathrm{ME}$ & $335.50 \pm 43.21$ & $\begin{array}{c}287.25 \pm 37.78 \\
(14.38 \%)\end{array}$ & $\begin{array}{c}227.75 \pm 35.33 \\
(32.12 \%)\end{array}$ & $\begin{array}{c}142.75 \pm 20.92 \\
(57.45 \%)^{* *}\end{array}$ & $\begin{array}{c}159.50 \pm 28.00 \\
(52.46 \%)\end{array}$ & $\begin{array}{c}90.00 \pm 2.38^{* *} \\
(73.17 \%)\end{array}$ & $\begin{array}{c}68.00 \pm 7.44 \\
(79.73 \%)\end{array}$ \\
\hline 3 & $400 \mathrm{mg} / \mathrm{kg}$ of $\mathrm{ME}$ & $337.75 \pm 17.63$ & $\begin{array}{c}263.00 \pm 37.92 \\
\quad(22.13 \%)\end{array}$ & $\begin{array}{c}256.00 \pm 23.28 \\
\quad(24.20 \%)\end{array}$ & $\begin{array}{c}206.75 \pm 36.89 \\
\quad(38.79 \%)\end{array}$ & $\begin{array}{c}128.75 \pm 7.43 \\
(61.88 \%)\end{array}$ & $\begin{array}{l}71.50 \pm 4.19 \\
(78.83 \%)^{* *}\end{array}$ & $\begin{array}{c}58.50 \pm 2.02 \\
(82.68 \%)\end{array}$ \\
\hline 4 & $\begin{array}{l}5 \mathrm{mg} / \mathrm{kg} \text { of } \\
\text { Glibenclamide }\end{array}$ & $346.75 \pm 27.84$ & $\begin{array}{c}313.25 \pm 51.30 \\
(9.66 \%)\end{array}$ & $\begin{array}{c}293.00 \pm 38.44 \\
\quad(15.50 \%)\end{array}$ & $\begin{array}{c}249.50 \pm 35.73 \\
(28.05 \%)\end{array}$ & $\begin{array}{c}180.75 \pm 34.58 \\
(47.87 \%)\end{array}$ & $\begin{array}{c}153.50 \pm 25.53 \\
(55.73 \%)\end{array}$ & $\begin{array}{c}105.75 \pm 28.14 \\
(69.50 \%)^{*}\end{array}$ \\
\hline 5 & $\begin{array}{c}2 \mathrm{mg} / \mathrm{kg} \text { of } 30 \% \\
\text { Tween } 80^{\mathrm{a}}\end{array}$ & $299.75 \pm 26.02$ & $\begin{array}{c}290.00 \pm 26.84 \\
(3.25 \%)\end{array}$ & $\begin{array}{c}265.00 \pm 22.36 \\
(11.59 \%)\end{array}$ & $\begin{array}{c}257.50 \pm 19.23 \\
(14.10 \%)\end{array}$ & $\begin{array}{c}232.00 \pm 26.04 \\
(22.60 \%)\end{array}$ & $\begin{array}{c}212.50 \pm 27.29 \\
(29.11 \%)\end{array}$ & $\begin{array}{c}191.25 \pm 26.06 \\
(36.20 \%)\end{array}$ \\
\hline
\end{tabular}

${ }^{a}$ Control group; Results are expressed as mean $\pm \operatorname{SEM}(n=4) ;{ }^{*} p<0.05{ }^{* *} p<0.01$ as compared with control group at the same time; one-way, ANOVA followed by Dunnet's t-test); figures in parenthesis denote mean percentage reduction of blood glucose from $0 \mathrm{~h}$.

best described property is their anti-oxidant capacity. Hence flavonoids are potent anti-oxidants. Other reported important biological activities of flavonoids include anti-bacterial, anti-cancinogenic, hepatoprotective and anti-viral effects. ${ }^{21}$ Alkaloids constitute an important class of structurally diversified compounds with various biological activities and each having its own specific mechanism of actions. The anti-oxidant, anti-cancer, anti-inflammatory, amoebocidal and antimicrobial activities of akaloids have been reported. ${ }^{22,23}$

The results of the acute toxicity study of crude methanol extract of Psydrax horizontalis in Table 2 showed no mortality on the selected mice at different test doses of the two phases. This implies that the $\mathrm{LD}_{50}$ was greater than $5000 \mathrm{mg} / \mathrm{kg}$ suggesting that the plant is relatively safe.

The result of the effect of methanol extract (ME) of Psydrax horizontalis in the normoglycemic rats showed a dose-dependent reduction in blood glucose concentration after acute and sub-acute administration as depicted in Table 3 . At a dose of $400 \mathrm{mg} / \mathrm{kg}$ of ME, $51.25 \%$ reduction in blood glucose concentration was recorded which was relatively greater than $200 \mathrm{mg} / \mathrm{kg}$ of $\mathrm{ME}(42.45 \%)$ and $100 \mathrm{mg} / \mathrm{kg}(40.59 \%)$ after 5 days of administration. The standard positive control, $5 \mathrm{mg} /$ $\mathrm{kg}$ of glibenclamide (GB) yielded $41.12 \%$ reduction in blood glucose concentration.

At $p<0.05$, there were no significant reductions in blood glucose concentrations for the two doses of ME. However, at $p<0.01$, significant reductions were noted for the $400 \mathrm{mg} / \mathrm{kg}$ of ME (39.38 and $51.25 \%$ at day 1 and day 5 respectively compared to the standard drug, $5 \mathrm{mg} / \mathrm{kg}$ glibenclamide and negative control, $2 \mathrm{ml} / \mathrm{kg}$ of $30 \%$ Tween 80. Glibenclamide, a known sulphonyurea, was used as the standard in the present study because it has been widely accepted as a standard drug in diabetic animal experiments associated with mild or moderate hyperglycaemia. ${ }^{8,24}$

The result of the effect of methanol extract (ME) of Psydrax horizontalis in the alloxan induced diabetic rats showed a dose-dependent reduction in blood glucose concentration after acute and sub-acute administration as depicted in Table 4.

At a dose of $100 \mathrm{mg} / \mathrm{kg}$, there was significant activity $(p<0.01)$ from the $3^{\text {rd }}$ hour up till the $3^{\text {rd }}$ day consecutively compared to the standard drug, $5 \mathrm{mg} / \mathrm{kg}$ glibenclamide which was significant at $(p<0.05)$ on the $5^{\text {th }}$ day. Also $200 \mathrm{mg} / \mathrm{kg}$ dose which had a significant activity $(p<0.01)$ only on the $6^{\text {th }}$ hour but with a higher percentage reduction $(79.73 \%)$ after 5days when compared to the standard drug (69.50\%). At $400 \mathrm{mg} /$ $\mathrm{kg}$ dose, $82.68 \%$ reduction in blood glucose concentration was recorded on the $5^{\text {th }}$ day.
The high percentage reduction of blood glucose concentration and significant anti-diabetic activity recorded with ME may be due to the presence of alkaloids, flavonoids, terpenoids and steroids present in them which have been reported to have likely anti-diabetic effects. ${ }^{3,7,8}$ One of the alkaloids that have been successfully employed as a hypoglycemic agent is Berberine, a quaternary ammonium salt from the protoberberine group of isoquinoline alkaloids. ${ }^{25}$

In a similar study conducted by ${ }^{12}$ on the effect of leaves of Psydrax parviflorum ethanol extract on STZ-induced diabetic rats, $200 \mathrm{mg} / \mathrm{kg}$ dose showed good hypoglycemic effect which was comparable to $5 \mathrm{mg} /$ $\mathrm{kg}$ glibenclamide. This confirms that the Psydrax genus have promising and interesting hypoglycemic and anti-diabetic activity.

In another antidiabetic study $b^{26}$, the methanol extract of the leaves of Psydrax parviflorum Lam. was reported to have significant antidiabetic activity in alloxan induced diabetic rats in a dose dependent manner which confirms the dose dependent reduction of blood glucose reduction observed in our study on the crude methanol extract of leaves Psydrax horizontalis Schumach. \& Thonn. Bridson.

Moreover, the anti-diabetic activities of the ethanol and methanol leaf extracts of Psydrax coromandelicum (Burm. f.) Alston which are close species of Psydrax horizontalis, have been reported to have shown significant decrease in blood glucose level and considerable improvement in all biochemical parameters. ${ }^{27}$ The mechanism of action via which the crude methanol extract was able to induce hypoglycemia in the alloxan-induced diabetic rats could be due to insulin release from undestroyed beta cells in the pancreas or its action may be similar to insulin in action as reported in similar study. ${ }^{26,27}$ Further fractionation and isolation of the bioactive compounds responsible for the antdiabetic activity is necessary.

\section{CONCLUSION}

Phytochemical analysis uncovers the secondary metabolites and bioactive compounds which are usually responsible for the pharmacological activities of a plant drug. Indigenous knowledge of plants play significant role in primary health care and are relevant sources for the discovery, design and development of novel drugs. The phytochemical constituents of Psydrax horizontalis (Schumach \& Thonn.) Bridson, Rubiaceae has been scientifically evaluated and its anti-diabetic activity in the traditional management of diabetes also validated.

\section{CONFLICTS OF INETERST}

The authors whose names are listed above certify that they have NO affiliations with or involvement in any organization or entity with any 
financial interest (such as honoraria; educational grants; participation in speakers' bureaus; membership, employment, consultancies, stock ownership, or other equity interest; and expert testimony or patentlicensing arrangements), or non-financial interest (such as personal or professional relationships, affiliations, knowledge or beliefs) in the subject matter or materials discussed in this manuscript.

\section{ACKNOWLDEGMENT}

Research fund was provided by The German Academic Exchange Service (DAAD-Deutscher Akademischer Austauschdienst) InCountry/In-Region Scholarship Scheme.

\section{ABBREVIATIONS}

P. horizontalis: Psydrax horizontalis; ME: Methaol extract, FBGC: Fasting Blood Glucose Concentration, ANOVA: One Way Analysis of Variance; GB: Glibenclamide; STZ: Streptozocin.

\section{REFERENCES}

1. Zaid H, Akhilesh KT, Mohammed SR and Thomas E. Diabetes and metabolism disorders medicinal plants: A glance at the past and a look to the future 2018. Evidence-Based Complementary and Alternative Medicine. 2018;1:1-3.

2. Jaacks LM, Siegel KR, Gujral UP and K.V. Narayan. Type 2 diabetes: A 21st century epideic. Best Practice \& Research Clinical Endocrinology \& Metabolism. 2016;30(3):331-43

3. Odoh UE and Ezugwu CO. Chromatographic and anti-diabetic studies on root extracts of Acanthus montanus (Acanthaceae). International Journal of Current Research. 2013;5(12):3719-22.

4. Aroda VR, Bain SC, Cariou B, Piletič M, Rose L, Axelsen M, et al. Efficacy and safety of once-weekly semaglutide versus once-daily insulin glargine as add-on to metformin (with or without sulfonylureas) in insulin-naive patients with type 2 diabetes (SUSTAIN 4): A randomised, open-label, parallelgroup, multicentre, multinational, phase $3 a$ trial. The Lancet Diabetes \& Endocrinology.2017;5(5):355-66

5. Pepato MT, Keller EH, Baviera AM, Kettelhut IC, Vendramini RC and Brunetti IL. Anti-diabetic activity of Bauhinia forficata decoctionin streptozotocin-diabetic rats. Journal of Ethnopharmacology. 2002;81:191-7.

6. Rajasekhar V, Kasetti B, Kondeti K and Chippada R. Antihyperglycemic and antihyperlipidemic activities of methanol:water (4:1) fraction isolated from aqueous extract of Syzygium alternifolium seeds in streptozotocin induced diabetic rats Food and Chemical Toxicology. 2010;48(4):1078-84.

7. Osadebe PO, Uzor PF, Omeje EO, Agbo MO, Obonga WO. Hypoglycemic activity of the extract and fractions of Anthocleista vogelii (Planch) Stem Bark. Tropical Journal of Pharmaceutical Research. 2014;13(9):1437-43.

8. Onyekere PF, Onyeke BU, Udodeme $\mathrm{HO}$ and Anosike C. Comparative antidiabetic activities of methanol and n-hexane extracts of Anthocleista vogelii in normoglycemic and alloxan-induced diabetic rats. ARC Journal of Pharmaceutical Sciences. 2017;3(2):1-8.
9. Gaertner J. De Fructibus et Seminibus Plantarum. Stuttgart Academiae, Carolina, Chapter 1; 1788.

10. Quattrochi U. CRC World Dictionary of Plant Names. Boca Raton, New York, Washington DC, London: CRC Press. Chapter 1. 2000. ISBN 978-0-8493-2675-2.

11. Bridson DM. The reinstatement of Psydrax (Rubiaceae, subfam. Cinchonoideae tribe Vanguerieae) and a revision of the African species. Kew Bulletin.1985;40(4):687-725.

12. Neelakanth MJ, Koti BC. Antidiabetic and Antihyperlipidemic Activity of Canthium parviflorum Extracts in Streptozotocin- Induced Diabetic Rats. RGUHS Journal of Pharmaceutical Sciences. 2015;5(4).

13. Mohideen S, Ilavarasan R, Hemalata S, Anitha N, Sasikala E. Wound healing and diuretic activities of Canthium parviflorum Lam. Natural Product Sciences Natural Product Sciences. 2006;9(2):102-4.

14. Ayyanar M, Sankarasivaraman K. Traditional herbal medicines used for the treatment of diabetes among two major tribal groups in South Tamil Nadu, India. Ethnobotanical Leaflets. 2008;12:276-80

15. Harbourne JB. Phytochemical methods of Analysis. Chapman and Hall, London. p.64-90. 1973.

16. Trease GE, Evans WC. Deterioration of stored Drugs Pharmacognosy. Braillar Tiriden Company, London. p.117-120; 1996.

17. Sofowora AE. Medicinal plants and Traditional Medicine in Africa. Spectrum Books Limited, Spectrum House, Ring Road Ibadan, Nigeria. p.79-81; 2008.

18. EEC. $86 / 609 / E E C$ of 24 November 1986 on the approximation of laws, regulations and administrative provisions of the Member States regarding the protection of animals used for experimental and other scientific purposes. Official Journal of the European Community, 29, L358.

19. Lorke D. A New Approach to Practical Acute Toxicity Testing. Archives of Toxicology. 1983;54:275-87

20. Pasumarth S, Murali KC, Chellu SC, Suresh C. Screening of phytochemical compounds in selected medicinal plants of Deccan Plateau and their viability effects on Caco-2 cells. Journal of Medicinal Plants Research. 2011;5:6955-62.

21. Kumar S, Pandey AK. Chemistry and biological activities of flavonoids: An overview. Scientific World Journal. 2013.

22. Kaur R, Arora S. Alkaloids-important therapeutic secondary metabolites of plant origin. Journal of Critical Reviews. 2015;2(3):1-8

23. Noureddine B. Pharmacological activity of Alkaloids: . Asian Journal of Botany 2018;1(1):1-6.

24. Owolabi OJ, Amaechina FC, Okoro M. Effect of ethanol leaf extracts of Newboulda laevis on blood glucose levels of diabetic rats. Tropical Journal of Pharmaceutical Research. 2011;10:249-54

25. Wang Y, Campbell T, Perry B, Beaurepaire C, Qin L. Hypoglycemic and insulin sensitizing effects of berberine in high-fat diet and streptozotocin-induced diabetic rats. Metabolism: Clinical and Experimental. 2010;60(2):298-305.

26. Pingale R, Ashish KS, Gouri KD. Antidiabetic activity of methanol extract of Canthium parviflorum Lam. Leaves. Indian Journal of Pharmaceutical and Biological Research. 2017;5(1):51-4.

27. Priyadarshini S, Ekambe BS, Surwase AP and Patil K. In vivo anti-inflammatory and antidiabetic potential of crude leaf extracts of Canthium coromandelicum (Burm. f.) Alston, Journal of Biologically Active Products from Nature. 2016;6(3):195-208. 


\section{GRAPHICAL ABSTRACT}

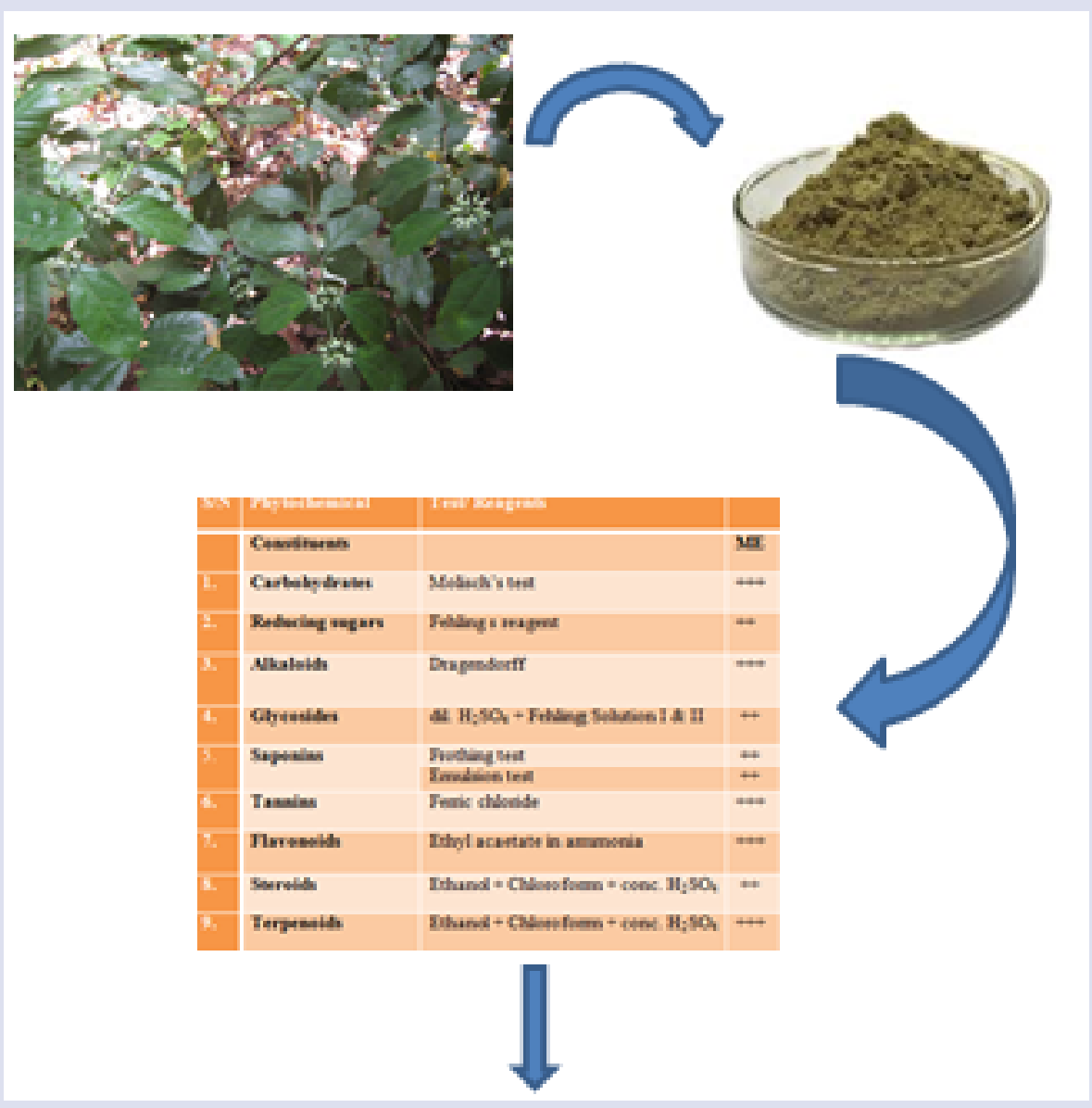

\section{ABOUT AUTHORS}

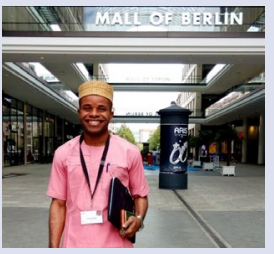

\section{ONYEKERE, Peculiar Feenna}

Pharmacist, Researcher \& Lecturer II

He is a DAAD research fellow and doctoral student. His research interest include natural product chemistry, phytochemistry and drug discovery/development for the treatment of chronic diseases such as diabetes and other oxidative degenerative diseases.

Affiliation:

a. Department of Pharmacognosy \& Environmental Medicine, Faculty of Pharmaceutical Sciences, University of Nigeria, Nsukka. 410001. Enugu State-Nigeria.

b. Department of Health Sciences, Hamburg University of Applied Sciences, HAW Hamburg, Germany.

E-mail: peculiar.onyekere@unn.edu.ng, peculiar.onyekere@daad-alumni.de Telephone: +2348068068346

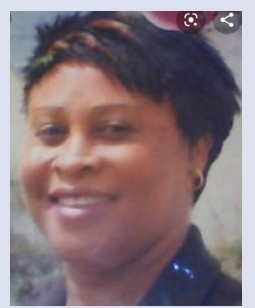

ODOH, Uchenna Estella

She is a Professor of Pharmacognosy \& Environmental Medicine. Her research interests include phytochemistry, natural product chemistry, drug evaluation and quality control. A supervisor to many undergraduate and postgraduate students in the Department.

Address: Department of Pharmacognosy \& Environmental Medicine, Faculty of Pharmaceutical Sciences, University of Nigeria, Nsukka. 410001. Enugu State, Nigeria.

E-mail: uchenna.odoh@unn.edu.ng

Phone No: +2348063831237 


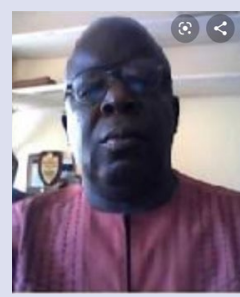

\section{EZUGWU, Christopher Obodoike}

He is a Professor of Pharmacognosy \& Environmental Medicine.

His research interests include ethnobotany and phytochemistry. He is the current Head of Department of Pharmacognosy \& Envrionmental Medicine. He has supervised many undergraduate and postgraduate students.

Affliation: Department of Pharmacognosy \& Environmental Medicine,

Faculty of Pharmaceutical Sciences, University of Nigeria, Nsukka. 410001. Enugu State, Nigeria.

E-mail: oechristo@yahoo.co.uk;

Phone No: +2348037786689

Cite this article: Onyekere PF, Odoh UE, Ezugwu CO. Phytochemical Analysis and Anti-diabetic Activity of Leaf extract of Psydrax horizontalis Schum. \& thonn (Rubiaceae). Pharmacog J. 2020;12(1):95-102. 